\title{
A full house of metastatic carcinoid disease
}

\author{
Rebecca Dobson, ${ }^{1}$ Malcolm Burgess, ${ }^{2}$ Hulya Wieshmann, ${ }^{2}$ Daniel Cuthbertson ${ }^{2}$ \\ ${ }^{1}$ Department of Endocrinology, University of Liverpool, Liverpool, UK \\ 2University Hospital Aintree, Liverpool, UK
}

Correspondence to Dr Rebecca Dobson, rebeccadobson@doctors.org.uk

\section{DESCRIPTION}

These are images of an elderly man presenting with back pain, weight loss and diarrhoea. Clinical examination revealed peripheral oedema, pan-systolic murmur and a nontender mass in his left iliac fossa. Abdominal CT revealed a calcified mass in the left iliac fossa with a characteristic spoke wheel appearance of carcinoid tumour (see arrow in figure 1) and solid and cystic liver lesions, consistent with multiple metastases.

An ${ }^{111}$ In-Octreotide examination demonstrated somatostatin-receptor-positive metastatic disease in the liver, abdominal lymph nodes and abnormal uptake in the bones, suggesting widespread skeletal metastases (figure 2 shows tumour sites identified by uptake of Octreotide, arrows indicate hepatic metastases and small bowel tumour). Transthoracic echocardiography revealed a thickened, immobile tricuspid valve, with mild tricuspid stenosis and severe regurgitation (figure 3; dense continuous wave Doppler signal through tricuspid valve representing severe tricuspid regurgitation). during the same hospital admission.

Neuroendocrine tumours are rare (incidence: 1.2-2.1 per 100000 of the general population per year ${ }^{1}$ ) malignancies originating from the enterochromaffin cells in the gastrointestinal tract, causing the release of vaso-active substances into the systemic circulation. The most common sites are the terminal ileum and appendix and up to $22 \%$ have evidence of liver metastases at diagnosis. ${ }^{2}$

Multiple imaging modalities assist in both the diagnosis of carcinoid disease and its complications. Large tumour burden, widespread disease and carcinoid heart disease are

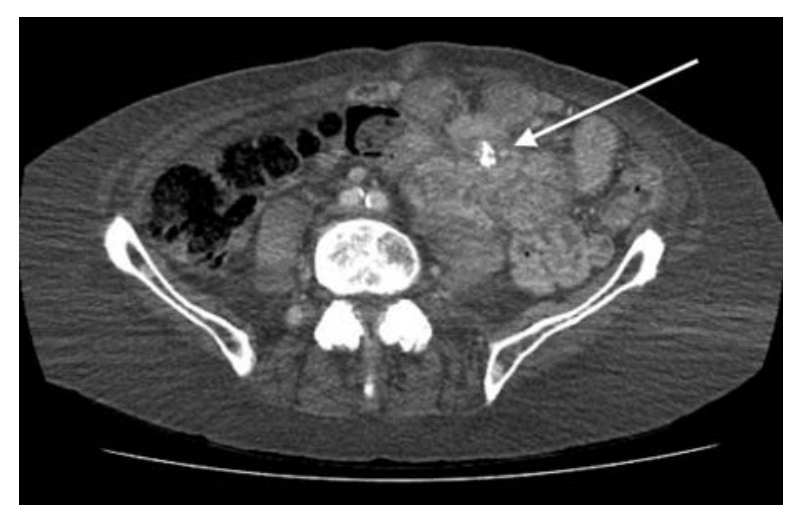

Figure 1 Abdominal CT scan.
Unfortunately, despite treatment, the patient died

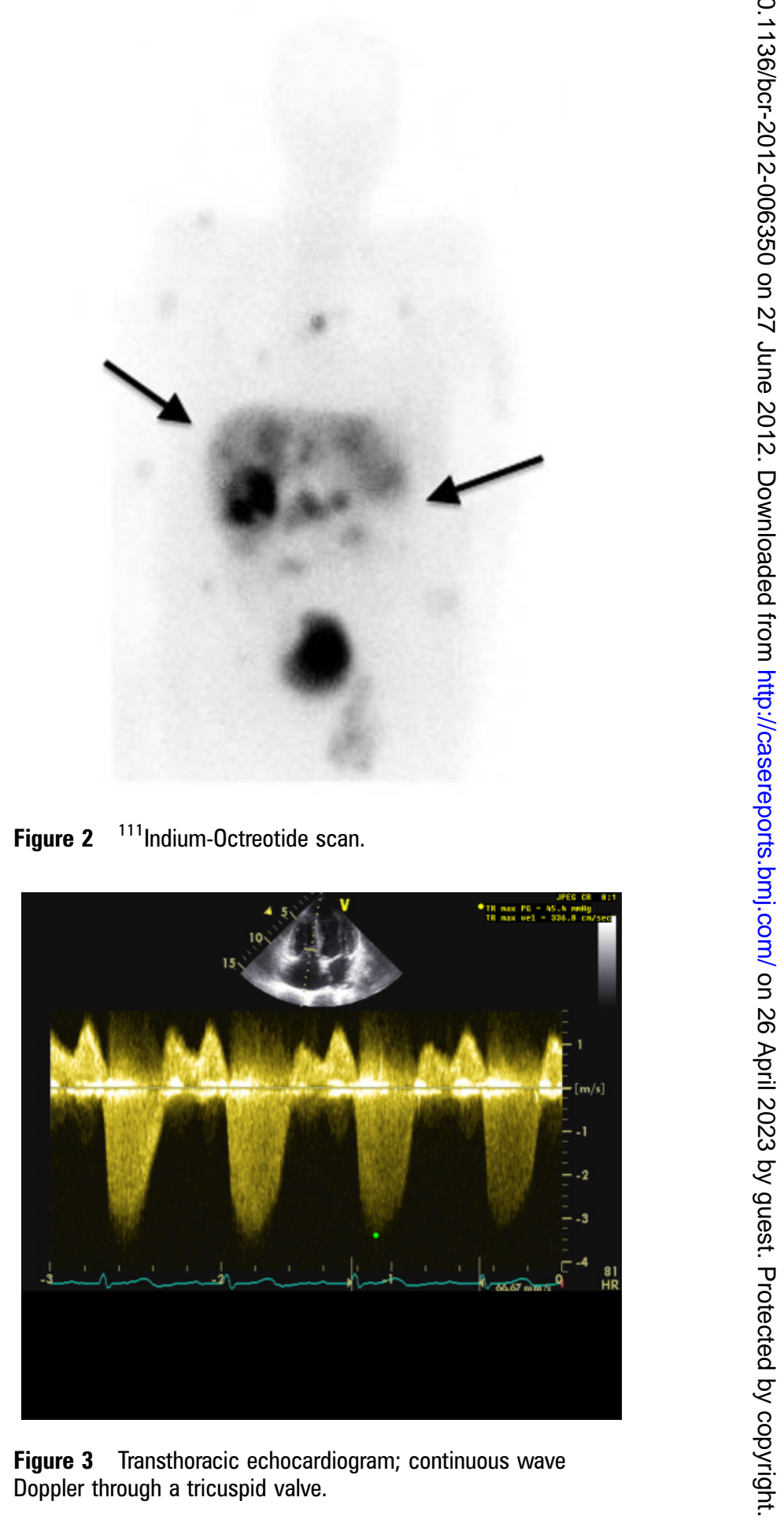




\section{BMJ Case Reports}

poor prognostic indicators, and as typified by our patient, a poor outcome is almost inevitable with the combination of these factors.

\section{Learning points}

An Octreoscan is a functional imaging modality that may be useful in localising the primary tumour site and in determining the extent of tumour burden in patients with neuroendocrine tumours.

- The combination of different imaging modalities may provide complementary information regarding disease burden and its multiple complications.

- Large tumour burden, widespread disease and carcinoid heart disease are poor prognostic indicators, and a poor outcome is almost inevitable with the combination of these factors.

\section{Competing interest None.}

Patient consent Obtained.

\section{REFERENCES}

1. Modin IM, Sander A. An analysis of 8305 cases of carcinoid tumours Cancer 1997; 79:813.

2. Zuetenhorst J, Taal B. Metastatic carcinoid tumours; a clinical review. Oncologist 2005;10:123-31.

This pdf has been created automatically from the final edited text and images.

Copyright 2012 BMJ Publishing Group. All rights reserved. For permission to reuse any of this content visit http://group.bmj.com/group/rights-licensing/permissions.

BMJ Case Report Fellows may re-use this article for personal use and teaching without any further permission.

Please cite this article as follows (you will need to access the article online to obtain the date of publication).

Dobson R, Burgess M, Wieshmann H, Cuthbertson D. A full house of metastatic carcinoid disease. BMJ Case Reports 2012;10.1136/bcr-2012-006350, Published XXX

Become a Fellow of BMJ Case Reports today and you can:

- Submit as many cases as you like

- Enjoy fast sympathetic peer review and rapid publication of accepted articles

- Access all the published articles

- Re-use any of the published material for personal use and teaching without further permission

For information on Institutional Fellowships contact consortiasales@bmjgroup.com

Visit casereports.bmj.com for more articles like this and to become a Fellow 